\title{
Collard green yield and nutritional quality with mineral and organic fertilization
}

\section{Produção e qualidade nutricional de couve-de-folha com adubação mineral e orgânica}

\author{
Fábio Steiner ${ }^{1}$; Alan Mario Zuffo ${ }^{2 *}$; Márcia de Moraes Echer ${ }^{3}$; \\ Vandeir Francisco Guimarães ${ }^{3}$
}

\begin{abstract}
A study was conducted to investigate the effect of organic and mineral fertilization on collard green yield, and to assess the macro and micronutrient and heavy metal concentrations of its leaves to assess the potential hazards of manure use. Collard plants (Brassica oleracea var. acephala, cv. couvemanteiga) were grown in 4-L pots filled with a clay soil under greenhouse conditions. The experimental design used was completely randomized design and the treatments in a $3 \times 4$ factorial arrangement: three $\mathrm{N}$ sources (pig slurry, poultry manure, and urea) and four $\mathrm{N}$ rates $\left(0,100,200\right.$ and $\left.300 \mathrm{mg} \mathrm{kg}^{-1}\right)$, with four replicates. Collard greens leaves were harvested 70 days after seedling plantings. The manure application (pig slurry or poultry manure) resulted in collard yield equivalent to the application of mineral fertilizer. However, the pig slurry application resulted in an increase of leaf $\mathrm{Fe}, \mathrm{Mn}, \mathrm{Zn}, \mathrm{Cd}$, $\mathrm{Cr}$, and $\mathrm{Pb}$ concentrations. Nitrogen application rates up to $300 \mathrm{mg} \mathrm{N} \mathrm{kg}^{-1}$ result in the higher yield and nutritional quality of collard leaves. The application of high rates of manure, especially pig slurry, results in the increase of heavy metal $(\mathrm{Cd}, \mathrm{Cr}$, and $\mathrm{Pb})$ concentrations. However, the maximum concentrations of $0.042 \mathrm{mg} \mathrm{kg}^{-1} \mathrm{Cd}, 0.034 \mathrm{mg} \mathrm{kg}^{-1} \mathrm{Cr}$ and $0.030 \mathrm{mg} \mathrm{kg}^{-1} \mathrm{~Pb}$ are well lower than maximum daily intake limit established by the Brazilian legislation, indicating that the consumption of collards from organic production systems with the manure application can be considered safe and without risk to human health.
\end{abstract}

Key words: Brassica oleraceae var. acephala. nutrient uptake. Organic manure. Heavy metal.

\section{Resumo}

Foi realizado um estudo para avaliar o efeito da aplicação de esterco e fertilizante mineral na produção e na qualidade nutricional de couve (Brassica oleracea var. acephala, cv. couve-manteiga). As plantas de couve foram cultivadas em vasos de $4 \mathrm{~L}$ preenchidos com um solo argiloso em condições de casa-devegetação. $\mathrm{O}$ delineamento experimental utilizado foi o inteiramente casualizado e os tratamentos em um arranjo fatorial $3 \times 4$ : três fontes de $\mathrm{N}$ (dejetos de suínos, esterco de aves e ureia) e quatro doses de $\mathrm{N}\left(0,100,200\right.$ e $\left.300 \mathrm{mg} \mathrm{kg}^{-1}\right)$, com quatro repetições. As folhas de couve foram colhidas 70 dias após o plantio das mudas. A aplicação de esterco (dejetos de suínos ou esterco de aves) resultou em rendimento de couve equivalente à aplicação de fertilizante mineral, indicando que o requerimento de nutrientes das

1 Prof., Universidade Estadual de Mato Grosso do Sul, UEMS, Unidade Universitária de Cassilândia, Cassilândia, MS, Brasil. E-mail: steiner@uems.br

2 Prof., Universidade Federal de Mato Grosso do Sul, UFMS, Campus Chapadão do Sul, Chapadão do Sul, MS, Brasil. E-mail: alan_zuffo@hotmail.com

3 Profs., Universidade Estadual do Oeste do Paraná, UNIOESTE, Campus de Marechal Cândido Rondon, Marechal Cândido Rondon, PR, Brasil. E-mail: mmecher@bol.com.br; vandeirfg@yahoo.com.br

* Author for correspondence

Received: Apr. 12, 2018 - Approved: June 18, 2019 
plantas foram totalmente atendidos pela aplicação de esterco animal. No entanto, a aplicação de dejetos de suínos resultou no aumento das concentrações de $\mathrm{Fe}, \mathrm{Mn}, \mathrm{Zn}, \mathrm{Cd}, \mathrm{Cr}$ e $\mathrm{Pb}$ nas folhas. A aplicação de $\mathrm{N}$ até a dose de $300 \mathrm{mg} \mathrm{kg}^{-1}$ indicou maior rendimento e melhor qualidade nutricional das folhas de couve. A aplicação de taxas elevadas de esterco, especialmente de dejeto suíno, implica no aumento da concentração de metais pesados nas folhas de couve. No entanto, as concentrações máximas obtidas de

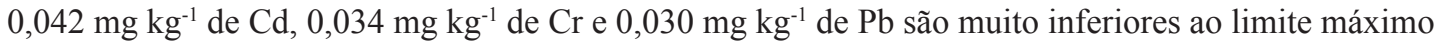
de consumo diário estabelecido pela legislação brasileira, indicando que o consumo de couve-de-folha oriunda dos sistemas de produção orgânicos com a aplicação de esterco animal pode ser considerado seguro e sem risco para a saúde humana.

Palavras-chave: Brassica oleraceae var. acephala. Extração de nutrientes. Esterco orgânico. Metal pesado.

\section{Introduction}

Collard green (Brassica oleracea L., var. acephala D.C.) is a biennial leafy vegetable of the Brassicaceae family. The collard green plants have large, broad, flat, smooth leaves with smooth leaf margins (FILGUEIRA, 2008). Popular cultivars of collard greens include 'Georgia Southern', 'Morris Heading', 'Butter Collard' (or couve-manteiga), and couve tronchuda. The couve-manteiga and couve tronchuda are especially appreciated in Brazil and Portugal. This vegetable has been prominent among the leafy vegetables by their higher content of protein, carbohydrates, fiber, vitamin-A, vitamin-C and minerals like iron, calcium, copper, manganese, selenium, and zinc (FILGUEIRA, 2008). Collard greens are also an excellent source of flavonoid poly-phenolic antioxidants such as lutein, carotenes, zeaxanthin, crypto-xanthin (KOPSELL et al., 2007). These compounds help to protect from lung and oral cavity cancers and chronic eye diseases as cataracts (GONG et al., 2006).

The yield and quality of collard green leaves are influenced by fertilizer management and climatic conditions, among other factors. Nitrogen $(\mathrm{N})$ is required in large amounts by collard green plants and plays a key role in the growth and yield of the product harvested (FILGUEIRA, 2008). In addition, the adequate $\mathrm{N}$ supply improves the nutritional quality of collard green for promoting the increase in carotenoid content (KOPSELL et al., 2007). However, the high application rates of $\mathrm{N}$ fertilizer can provide excess $\mathrm{N}$, with consequent nitrate accumulation and decreased quality of the product (ZAGO et al., 1999), as well as the production cost burdening. Thus, studies aimed at establishing adequate $\mathrm{N}$ rates are of extreme importance so that the total quality is achieved in the productive process.

One alternative to reduce production costs of vegetables is the use of organic fertilization with animal manure. The use of animal manure as fertilizer has been an important management strategy for the improvement of soil structural quality (ARRUDA et al., 2010) and fertility (SILVA et al., 2007). Manure application provides an excellent nutrient source for plants providing conditions for obtaining higher yields (ABREU et al., 2010). In addition, organic fertilizers have a process of decomposition and release nutrient slower favorable condition for the increased production of collard (ZAGO et al., 1999), due mainly of the synchronization between the nutrients released from manure and greater demand of the crop. This inference is justified due to the long cycle of the crop, which can remain productive for over a year.

Studies have shown that organic fertilization has provided collard green yield similar to mineral fertilizer application (ZAGO et al., 1999; SHINGO; VENTURA, 2009). However, the effects of 'in nature' manure application on collard yield are still unknown. On the other hand, points out that the use of animal manure on vegetable production must be monitored to limit the potential for chemical and/ or microbiological contamination (ABREU et al., 2010) and, therefore the final quality of vegetables commercialized.

The objectives of the present study were to compare the effects of different source and rates 
of mineral and organic fertilizers on collard green yield, and to assess the macro- and micronutrient and heavy metal concentrations of its leaves to assess the potential hazards of organic fertilizer use.

\section{Material and Methods}

The experiment was conducted in a greenhouse at the Western Parana State University, in Marechal Cândido Rondon, Paraná, Brazil (24³1' S, 54º1' $\mathrm{W}$, and altitude of $420 \mathrm{~m}$ ), where the environmental conditions were: minimum and maximum mean air temperature of 18 and $36{ }^{\circ} \mathrm{C}$, respectively; mean air relative humidity of $60 \%$. The soil used in the experiment was collected from the plough layer of a Rhodic Hapludox (Red Latosol in the Brazilian classification) with $620 \mathrm{~g} \mathrm{~kg}^{-1}$ of clay, $110 \mathrm{~g} \mathrm{~kg}^{-1}$ of silt, and $270 \mathrm{~g} \mathrm{~kg}^{-1}$ of sand. The soil had the following properties: $\mathrm{pH}\left(1: 2.5 \mathrm{soil} / \mathrm{CaCl}_{2}\right.$ suspension $\left.0.01 \mathrm{M}\right)$ $5.1,30 \mathrm{~g} \mathrm{dm}^{-3}$ of organic matter, $12 \mathrm{mg} \mathrm{dm}^{-3}$ of $\mathrm{P}_{\text {Mehlich- } 1}, 32 \mathrm{mmol}_{\mathrm{c}} \mathrm{dm}^{-3}$ of Ca, $17 \mathrm{mmol}_{\mathrm{c}} \mathrm{dm}^{-3}$ of $\mathrm{Mg}$, $2.8 \mathrm{mmol}_{\mathrm{c}} \mathrm{dm}^{-3} \mathrm{~K}, 105 \mathrm{mmol}_{\mathrm{c}} \mathrm{dm}^{-3}$ of CEC, $50 \%$ of base saturation, $9.5 \mathrm{mg} \mathrm{dm}^{-3}$ of $\mathrm{Cu}_{\text {Mehlich-1 }}, 2.6 \mathrm{mg}$ $\mathrm{dm}^{-3}$ of $\mathrm{Zn}_{\text {Mehlich-1 }}, 41 \mathrm{mg} \mathrm{dm}{ }^{-3}$ of $\mathrm{Fe}_{\text {Mehlich-1 }}, 128 \mathrm{mg}$ $\mathrm{dm}^{-3}$ of $\mathrm{Mn}_{\text {Mehlich-1 }}, 0.0 \mathrm{mg} \mathrm{dm}^{-3}$ of $\mathrm{Cd}_{\text {Mehlich-1 }}, 0.8 \mathrm{mg}$ $\mathrm{dm}^{-3}$ of $\mathrm{Pb}_{\text {Mehlich-1 }}$, and $0.3 \mathrm{mg} \mathrm{dm}^{-3}$ of $\mathrm{Cr}_{\text {Mehlich-1. }}$. All the soil chemical properties were analyzed according to Donagema et al. (2011). Lime (28\% CaO, 12\% MgO and ECC 96\%) was applied before the experiment to raise base saturation up to $70 \%$, according to Sousa and Lobato (2004). The limed soil was kept in plastic bags for 15 days with water content at field capacity.

The treatments consisted of three nitrogen sources (pig slurry, poultry manure, and urea) and four nitrogen rates $(0,100,200$ and $300 \mathrm{mg}$ $\left.\mathrm{N} \mathrm{kg}{ }^{-1}\right)$. In the treatments fertilized with urea (mineral fertilization) were also applied $200 \mathrm{mg} \mathrm{P}$ $\mathrm{kg}^{-1}$ (simple superphosphate) and $150 \mathrm{mg} \mathrm{K} \mathrm{kg}{ }^{-1}$ (potassium chloride). The $\mathrm{N}$ rates as urea $(45 \% \mathrm{~N})$ was applied in topdressing at 7, 14 and 28 days after transplanting at $30 \%, 30 \%$ and $40 \%$, respectively, of the rate evaluated. The urea rates per pot were applied as a $20-\mathrm{mL}$ solution, previously diluted in pure water, to the side of each plant. The main physicochemical characteristics of pig slurry and poultry manure are shown in table 1 .

Table 1. Physical and chemical characteristics of pig slurry and poultry manure used in the study.

\begin{tabular}{|c|c|c|}
\hline Characteristic & Pig slurry & Poultry manure \\
\hline $\mathrm{pH}$ in water & 7.2 & 8.5 \\
\hline Dry matter $\left(\mathrm{g} \mathrm{kg}^{-1}\right)$ & 25.0 & 770.0 \\
\hline Total nitrogen $\left(\mathrm{g} \mathrm{kg}^{-1}\right)$ & 3.2 & 10.3 \\
\hline Total phosphorus $\left(\mathrm{g} \mathrm{kg}^{-1}\right)$ & 0.4 & 2.0 \\
\hline Potassium $\left(\mathrm{g} \mathrm{kg}^{-1}\right)$ & 0.7 & 4.0 \\
\hline Calcium $\left(\mathrm{g} \mathrm{kg}^{-1}\right)$ & 15.1 & 32.1 \\
\hline Magnesium $\left(\mathrm{g} \mathrm{kg}^{-1}\right)$ & 6.8 & 9.7 \\
\hline Sulfur $\left(\mathrm{g} \mathrm{kg}^{-1}\right)$ & 0.1 & 2.7 \\
\hline Copper $\left(\mathrm{mg} \mathrm{kg}^{-1}\right)$ & 87.0 & 31.1 \\
\hline Iron $\left(\mathrm{mg} \mathrm{kg}^{-1}\right)$ & 438.0 & 39.8 \\
\hline Manganese (mg kg-1) & 33.4 & 121.3 \\
\hline Zinc $\left(\mathrm{mg} \mathrm{kg}^{-1}\right)$ & 332.0 & 17.9 \\
\hline Cadmium (mg kg-1) & 2.0 & n.d. ${ }^{\dagger}$ \\
\hline Lead $\left(\mathrm{mg} \mathrm{kg}^{-1}\right)$ & 8.0 & n.d. ${ }^{\dagger}$ \\
\hline Chromium $\left(\mathrm{mg} \mathrm{kg}^{-1}\right)$ & 2.0 & n.d. ${ }^{\dagger}$ \\
\hline
\end{tabular}


Collard seedlings (Brassica oleraceae var. acephala, cv. couve-manteiga) produced in 128cell expanded polystyrene trays filled with the commercial substrate $\left(\right.$ Plantmax $\left.^{\circledR}\right)$ were used. At 21 days after sowing, when they presented four leaves, the seedlings were transplanted in 4-L plastic pots. Each experimental unit consisted of one pot containing one collard plant. The soil water content was monitored daily and maintained near at the field capacity.

Collard leaves were harvested 70 days after planting the seedlings. In the laboratory, leaves were washed following the same procedures as for food preparation to remove any surface deposits (CHARY et al., 2008). Then, the leaves were rewashed with deionized water, oven-dried at $60^{\circ} \mathrm{C}$ for $72 \mathrm{~h}$, weighed and finely ground in a Willey mill.

A $500 \mathrm{mg}$ dried sample was digested in a digestion block, with a nitric acid $\left(\mathrm{HNO}_{3}\right)$ and perchloric acid $\left(\mathrm{HClO}_{4}\right)$ mixture $(3: 1 ; \mathrm{v}: \mathrm{v})$ in Pyrex tubes (MIYAZAWA et al., 2009). After cooling they were diluted to a final volume of $25 \mathrm{~mL}$ with deionized water. All analyses were processed in triplicate. Total $\mathrm{K}, \mathrm{Ca}, \mathrm{Mg}, \mathrm{Cu}, \mathrm{Fe}, \mathrm{Mn}, \mathrm{Zn}, \mathrm{Cd}, \mathrm{Pb}$, and $\mathrm{Cr}$ concentrations were analyzed by atomic absorption spectrophotometry (Varian-Spectra 250 PLUS). Total P concentration was analyzed by molybdenum blue phosphorus method using a UV-visible spectrophotometer (Perkin Elmer-Lambda 3B). The $\mathrm{S}$ concentration was analyzed by turbidimetry method using a UV-visible spectrophotometer (Perkin Elmer-Lambda 3B). Total N concentration was determined by the Kjeldahl method with digestion in sulfuric acid solution and vapor distillation as described by Miyazawa et al. (2009). The accuracy of the different methods was verified by analyzing the standard reference material.

The experiment was arranged in a completely randomized design, in a factorial, with three $\mathrm{N}$ sources (pig slurry, poultry manure and urea) and four $\mathrm{N}$ rates $\left(0,100,200\right.$ and $300 \mathrm{mg} \mathrm{kg}^{-1}$ of $\left.\mathrm{N}\right)$, with four replications (an individual pot containing one plant represented one replicate). The normality of data was previously tested by the KolmogorovSmirnov test at the 5\% level and then data were analyzed by analysis of variance (ANOVA) and the multiple comparisons of means by Tukey's test of $\mathrm{N}$ sources at the 0.05 confidence level. Regression analysis was used for the $\mathrm{N}$ rates, and significant equations with the highest coefficients of determination ( $\mathrm{F}$ test, $p<0.05$ ) were adjusted. All analyses were performed using SigmaPlot 11.0 software for Windows (Systat Software, Inc., San Jose, CA, USA).

\section{Results and Discussion}

\section{Collard green yield}

The manure application (pig slurry or poultry manure) resulted in collard green yield similar to the application of mineral fertilizer (Table 2). These results indicate that the nutrient requirements of collard green plants were fully met by the application of animal manure. Research results show distinct responses to fertilizer sources on leafy vegetable yield. Zago et al. (1999) evaluated the effect of urea, cattle manure and biofertilizer also found no significant differences between these sources in the collard yield, supporting the results presented here. Shingo and Ventura (2009) also verified that organic fertilization with different organic compounds and pyroligneous acid resulted in collard green yield similar to standard fertilization with mineral fertilizer.

However, Xu et al. (2003) reported that organic fertilization improved the growth of Brassica rapa L. and Brassica campestres L., resulting in the final higher total yield compared to the mineral fertilization. These authors attributed this beneficial effect of manure application due to the high nutrient sustainability of organic fertilizer and the improved biological properties of the soil. Lim and Vimala (2012) verified that the application of $10 \mathrm{Mg} \mathrm{ha}^{-1}$ poultry manure resulted in the lower yields of leaf mustard (Brassica juncea), kangkung (Ipomoea 
reptans), chinese spinach (Amaranthus sp.) and lettuce (Lactuca sativa) than the application of mineral fertilizer alone. Therefore, to obtain leafy vegetable yields comparable to the application of mineral fertilizer the rate of poultry manure applied should be higher to meet nutrient requirements.
The results obtained in this study indicate that it is possible for organic farming to produce leafy vegetables with high quality and a yield higher than or similar to that of mineral farming if the nutrient supply is sufficient.

Table 2. Effect of sources and rates of nitrogen application on the number of leaves per plant, leaves fresh mass and dry mass of collard green plants (Brassica oleraceae var. acephala, cv. couve-manteiga).

\begin{tabular}{lccc}
\hline \multicolumn{1}{c}{ Nitrogen sources } & Number of leaves per plant & Leaves fresh mass & Leaves dry mass \\
\hline & units & --------- g plant $^{-1}$ & -------- \\
Pig slurry & $11.1 \mathrm{a}$ & $68.6 \mathrm{a}$ & $9.8 \mathrm{a}$ \\
Poultry manure & $10.9 \mathrm{a}$ & $65.0 \mathrm{a}$ & $9.8 \mathrm{a}$ \\
Urea & $11.1 \mathrm{a}$ & $72.4 \mathrm{a}$ & $10.9 \mathrm{a}$ \\
\hline F test & & F value & $3.21 \mathrm{~ns}$ \\
\hline Source $(\mathrm{S})$ & $0.19 \mathrm{~ns}$ & $2.45 \mathrm{~ns}$ & $33.49^{* *}$ \\
Rate (R) & & & $3.20 \mathrm{~ns}$ \\
Linear regression & $3.09 \mathrm{~ns}$ & $32.22^{* *}$ & $0.97 \mathrm{~ns}$ \\
Quadratic regression & $0.14 \mathrm{~ns}$ & $8.10^{* *}$ & 13.8 \\
Interaction $(\mathrm{S} \times \mathrm{R})$ & $0.23 \mathrm{~ns}$ & $0.34 \mathrm{~ns}$ & 14.4 \\
\hline CV $(\%)$ & 5.0 & &
\end{tabular}

Values represented by the different letters, for the nitrogen source show significant differences (Tukey test, $\mathrm{p}<0.05$ ). ns: not significant. $*$ and $* *$ : statistical significance at $5 \%$ and $1 \%$, respectively, by $\mathrm{F}$ test. $\mathrm{CV}$ : coefficient of variation.

The yield of collard greens increased significantly with $\mathrm{N}$ rates (Figure 1). Leaf fresh mass increased from 53.7 g plant $^{-1}$ in the unfertilized control with $\mathrm{N}$ to a maximum of $77.2 \mathrm{~g} \mathrm{plant}^{-1}$ with the application of $242 \mathrm{mg} \mathrm{N} \mathrm{kg}^{-1}$, indicating a mean increase of $44 \%$ (Figure 1A). The application of $300 \mathrm{mg} \mathrm{N} \mathrm{kg}^{-1}$ had a linear increased the leaf dry mass in $37 \%$ (from 8.6 to $\left.11.8 \mathrm{~g} \mathrm{plant}^{-1}\right)$ compared to the unfertilized control with N (Figure 1B). Therefore, the optimal $\mathrm{N}$ application rate for collard greens grown in protected environments may range between 240 and $300 \mathrm{mg} \cdot \mathrm{N} \mathrm{kg}^{-1}$. In general, high $\mathrm{N}$ fertilizer rates are used to increase crucifer yields.

A positive response to $\mathrm{N}$ fertilizer application up to $105 \mathrm{mg} \cdot \mathrm{N} \mathrm{kg}^{-1}$ was reported in mock pakchoi (Brassica chinensis L. var. parachinensis) by Zanão Júnior et al. (2005). The response of pak-choi (Brassica campestris var. chinensis L.) to $\mathrm{N}$ fertilizer rates occurred until the application of $195 \mathrm{mg} \cdot \mathrm{N}$ $\mathrm{kg}^{-1}$ (DARTORA et al., 2013). Linear increases in marketable broccoli yields and head weights were obtained with up to $250 \mathrm{~kg} \mathrm{~N}^{-1}$ (AMBROSINI et al., 2015). These results were expected because $\mathrm{N}$ is the nutrient required in large amounts by collard green plants (FILGUEIRA, 2008), since it is a constituent of amino acids, proteins, enzymes, and the chlorophyll molecule, with a marked effect on photosynthesis and therefore on crop growth and final yield (TAIZ et al., 2017).

The different $\mathrm{N}$ sources significantly affected $(p<0.05)$ the macronutrient concentrations in the collard leaves, except for $\mathrm{K}$ and $\mathrm{Mg}$ (Tabela 3). Still, in this table, leaf $\mathrm{N}$ concentration ranged from 29.0 to $35.7 \mathrm{~g} \mathrm{~kg}^{-1}$ and, was significantly greater with the application of mineral fertilizer (urea), and lower with the application of fertilizer organic 
(pig slurry or poultry manure. Zago et al. (1999) also reported that the application of urea resulted in higher $\mathrm{N}$ concentration in the collard leaves when compared to the cattle manure addition. The higher $\mathrm{N}$ uptake with the mineral fertilizer application was due to the high solubility of the urea, resulting in an increase in the availability of this nutrient in the soil.
In turn, the use of organic fertilizer results in the slow and gradual release of nutrients from manure to the soil solution. Indeed, only $80 \%$ and $50 \%$ of the total $\mathrm{N}$ present in pig slurry and poultry manure, respectively, are released during the first year of cropping (KONZEN; ALVARENGA, 2005).

Figure 1. Effect of nitrogen application rates on the leaf fresh mass (A) and dry mass (B) of collard green (Brassica oleraceae var. acephala, $\mathrm{cv}$. couve-manteiga) plants. Data refer to mean values $(\mathrm{n}=4)$.**: statistical significance at $1 \%$ by $\mathrm{F}$ test.
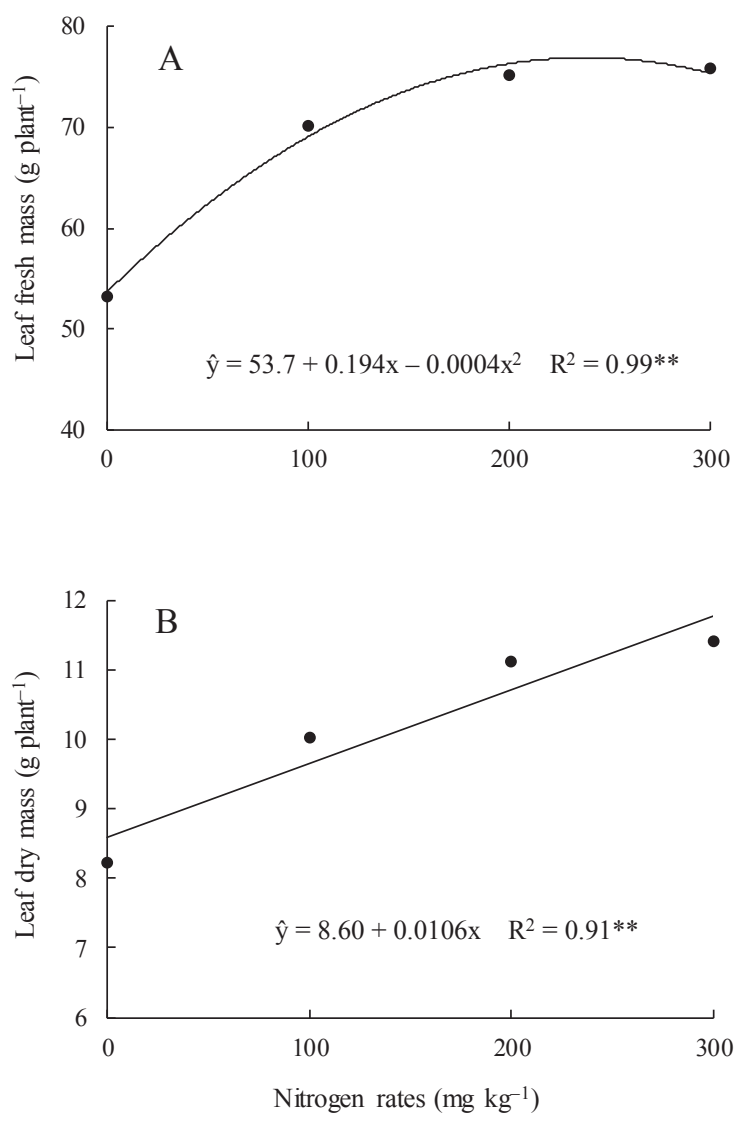

Leaf $\mathrm{P}$ and $\mathrm{Ca}$ concentrations were significantly higher with the application of urea and poultry manure, and lower in the treatment with pig slurry (Table 3). In these two macronutrients, the linear and quadratic effects were significant and for the others, only the linear effect presented statistical significance. Leaf $\mathrm{S}$ concentration ranged from 5.2 to $6.3 \mathrm{~g} \mathrm{~kg}^{-1}$, and was significantly higher with poultry manure application, and lower with the addition of urea and pig slurry (Table 3 ). The lower $\mathrm{P}, \mathrm{Ca}$ and $\mathrm{S}$ concentrations in the collard leaves with the addition of pig slurry may be due to the smaller amount of these nutrients in this source of fertilization (Table 1).

Nitrogen application rates significantly influenced $(p<0.05)$ the concentration of all macronutrients, indicating that the nutritional quality of collard 
leaves is dependent of the appropriate supply of $\mathrm{N}$. Leaf $\mathrm{N}, \mathrm{K}, \mathrm{Mg}$ and $\mathrm{S}$ concentrations increased linearly in response to $\mathrm{N}$ fertilizer rate (Figure 2). The application of $300 \mathrm{mg} \mathrm{N} \mathrm{kg}^{-1}$ increased the leaf $\mathrm{N}, \mathrm{K}, \mathrm{Mg}$ and $\mathrm{S}$ concentrations in $84 \%, 21 \%, 22 \%$, and $23 \%$, respectively, compared to the unfertilized control with N (Figure 2). On the other hand, leaf $\mathrm{P}$ and $\mathrm{Ca}$ concentrations had a quadratic effect in response to $\mathrm{N}$ rate, and the maximum concentration of $\mathrm{P}\left(12.0 \mathrm{~g} \mathrm{~kg} \mathrm{k}^{-1}\right)$ and $\mathrm{Ca}\left(37.3 \mathrm{~g} \mathrm{~kg}^{-1}\right)$ was obtained with the application of 194 and $268 \mathrm{mg} \mathrm{N} \mathrm{kg}^{-1}$, respectively (Figures 2B and 2D). The significant increase in macronutrient concentration in the leafy vegetable leaves in response to application rates between 170 and $210 \mathrm{mg} \mathrm{kg}^{-1}$ of $\mathrm{N}$ has been commonly reported under protected cultivation conditions (ZANÃO JÚNIOR et al., 2005; KANO et al., 2010; AMBROSINI et al., 2015).

Table 3. Effect of sources and rates of nitrogen application on the leaf macronutrient concentration of the collard greens (Brassica oleraceae var. acephala, cv. couve-manteiga).

\begin{tabular}{|c|c|c|c|c|c|c|}
\hline Nitrogen source & $\mathrm{N}$ & $\mathrm{P}$ & $\mathrm{K}$ & $\mathrm{Ca}$ & $\mathrm{Mg}$ & $\mathrm{S}$ \\
\hline & \multicolumn{6}{|c|}{ 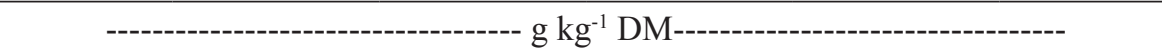 } \\
\hline Pig slurry & $31.5 \mathrm{~b}$ & $9.1 \mathrm{~b}$ & $17.8 \mathrm{a}$ & $31.3 \mathrm{~b}$ & $4.2 \mathrm{a}$ & $5.6 \mathrm{~b}$ \\
\hline Poultry manure & $29.0 \mathrm{~b}$ & $12.2 \mathrm{a}$ & $17.1 \mathrm{a}$ & $33.9 \mathrm{a}$ & $4.0 \mathrm{a}$ & $6.3 \mathrm{a}$ \\
\hline Urea & $35.7 \mathrm{a}$ & $11.8 \mathrm{a}$ & $18.7 \mathrm{a}$ & $35.6 \mathrm{a}$ & $4.1 \mathrm{a}$ & $5.2 \mathrm{~b}$ \\
\hline F test & \multicolumn{6}{|c|}{ F value } \\
\hline Source $(\mathrm{S})$ & $10.49 * *$ & $6.15^{* *}$ & $1.78 \mathrm{~ns}$ & $6.32 * *$ & $1.29 \mathrm{~ns}$ & $3.80^{*}$ \\
\hline \multicolumn{7}{|l|}{ Rate (R) } \\
\hline Linear regression & $135.9 * *$ & $6.67 * *$ & $12.00 * *$ & $61.16^{* *}$ & $44.96 * *$ & $32.64 * *$ \\
\hline Quadratic regression & $0.01 \mathrm{~ns}$ & $3.76^{*}$ & $0.46 \mathrm{~ns}$ & $8.95^{* *}$ & $2.61 \mathrm{~ns}$ & $1.28 \mathrm{~ns}$ \\
\hline Interaction $(\mathrm{S} \times \mathrm{R})$ & $1.42 \mathrm{~ns}$ & $0.80 \mathrm{~ns}$ & $0.24 \mathrm{~ns}$ & $0.86 \mathrm{~ns}$ & $0.10 \mathrm{~ns}$ & $1.14 \mathrm{~ns}$ \\
\hline CV $(\%)$ & 13.0 & 24.1 & 13.8 & 9.7 & 7.6 & 8.4 \\
\hline
\end{tabular}

Values represented by the different letters, for the nitrogen source show significant differences (Tukey test, $\mathrm{p}<0.05$ ). ns: not significant. $*$ and $* *$ : statistical significance at $5 \%$ and $1 \%$, respectively, by $\mathrm{F}$ test. $1 \%$. CV: coefficient of variation.

Figure 2. Effect of nitrogen application rates on the concentration of nitrogen (A), phosphorus (B), potassium (C), calcium (D), magnesium (E) and sulfur (F) of the collard green (Brassica oleraceae var. acephala, cv. couve-manteiga) leaves. Data refer to mean values $(\mathrm{n}=4)$. * and **: statistical significance at $5 \%$ and $1 \%$, respectively, by $\mathrm{F}$ test.
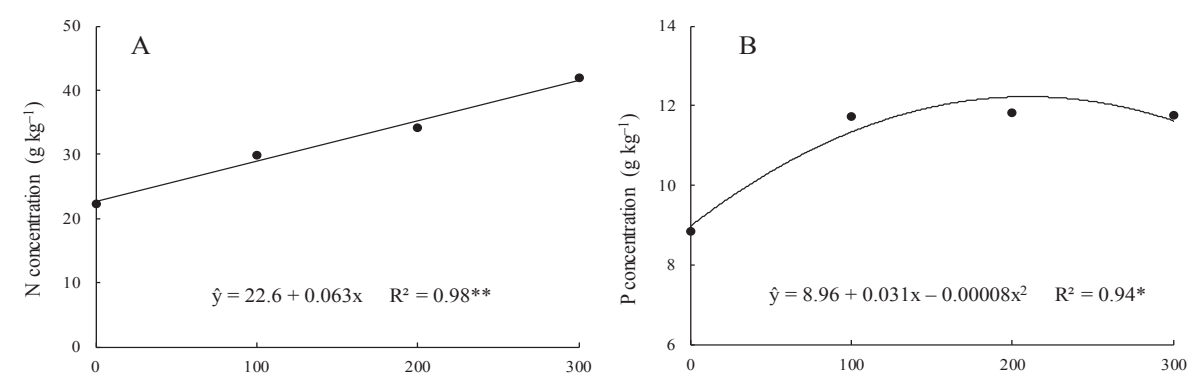

continue 
continuation
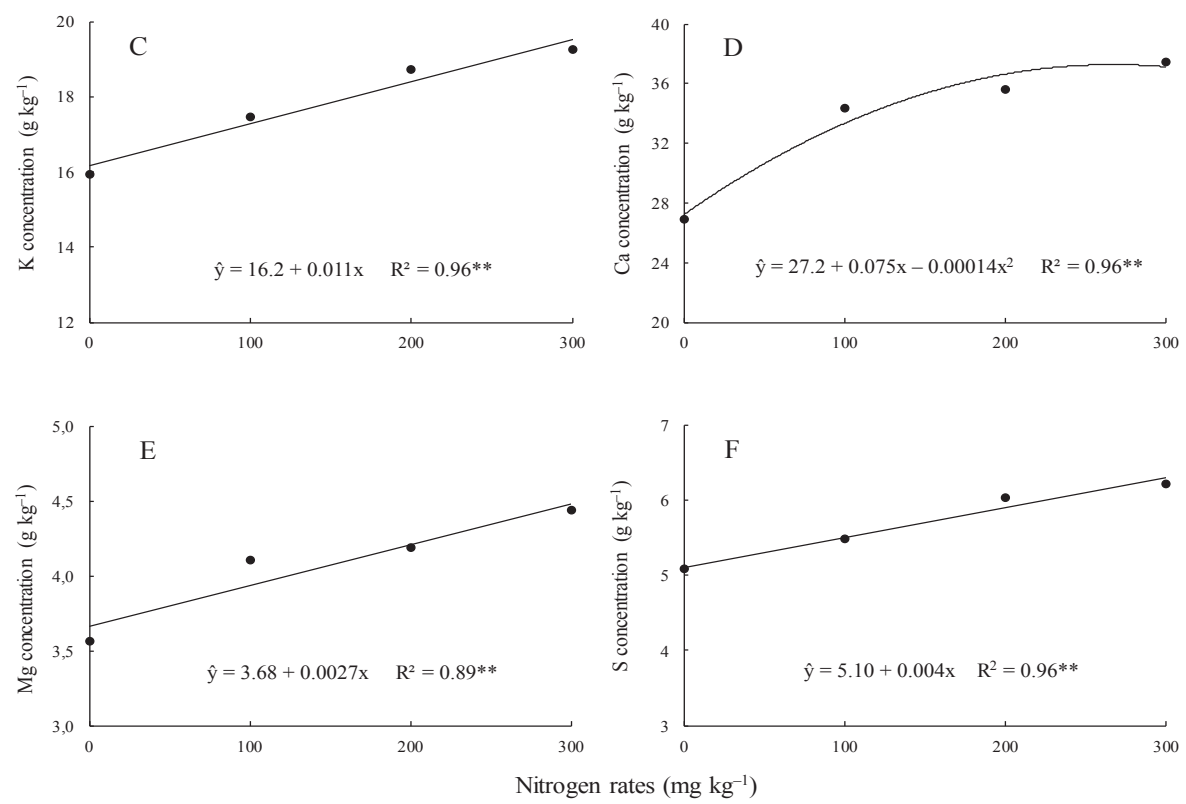

Only in the unfertilized control treatment, the $\mathrm{N}$ concentrations in the leaves were lower than 30 to 55 $\mathrm{g} \mathrm{kg}^{-1}$ (Figure 1A), the range considered appropriate for collards by Trani and Raij (1997). Leaf P and Ca concentrations in all treatments exceeded the range of 3.0-7.0 and 13-25 $\mathrm{g} \mathrm{kg}^{-1}$, respectively, considered adequate by Trani and Raij (1997), possibly due to fact that the availability of these nutrients in the soil $\left(12 \mathrm{mg} \mathrm{dm}^{-3}\right.$ of $\mathrm{P}$ and $32 \mathrm{mmol} \mathrm{dm}^{-3}$ of $\left.\mathrm{Ca}\right)$ is considered high (SOUSA; LOBATO, 2004).

The $\mathrm{K}$ concentration was lower than the sufficiency range (20-40 $\mathrm{g} \mathrm{kg}^{-1}$ ) for collards (TRANI; RAIJ, 1997). Leaf $\mathrm{Mg}$ and $\mathrm{S}$ concentrations in all treatments were within sufficiency range for collards (TRANI; RAIJ, 1997), i.e., 2.5-7.0 $\mathrm{g} \mathrm{kg}^{-1}$ for $\mathrm{Mg}$, and 3.0-7.0 $\mathrm{g} \mathrm{kg}^{-1}$ for $\mathrm{S}$. Except for $\mathrm{K}$, these results show that the nutrient supply for the plants was sufficient for optimum collard green growth.

Although the macronutrient accumulation in the leaves was increased at higher $\mathrm{N}$ rates (Figure 2), in the average of all treatments, the nutrient uptake by the collards occurred in the following order: $\mathrm{N}=\mathrm{Ca}$ $>\mathrm{K}>\mathrm{S}>\mathrm{P}>\mathrm{Mg}$. Different results were reported by Zanão Júnior et al. (2005), who verified a higher extraction of $\mathrm{K}, \mathrm{N}, \mathrm{Ca}, \mathrm{S}, \mathrm{P}$, and $\mathrm{Mg}$, respectively, by the mock pak-choi plants (Brassica chinensis L. var. parachinensis). However, these results clearly show the importance of providing adequate rates of $\mathrm{N}$, Ca and $\mathrm{K}$. These three nutrients are needed in larger quantities by collard plants compared to other nutrients.

The N sources significantly affected $(p<0.05)$ the concentration of micronutrients and toxic heavy metals in collard leaves, except for $\mathrm{Cu}$ (Table 4). Leaf $\mathrm{Fe}, \mathrm{Mn}, \mathrm{Zn}$ and $\mathrm{Cr}$ concentrations were significantly higher with the application of pig slurry, and lower in the treatments with urea and poultry manure (Table 4). Leaf $\mathrm{Cd}$ and $\mathrm{Pb}$ concentrations were significantly greater when plants were fertilized with pig slurry, followed by addition of poultry manure, and lower treatment with application of mineral fertilizer (urea) (Table 4). The higher heavy metal concentrations in collard leaves with the use of manure, especially with the application of pig slurry, was due to the presence of these elements in the manure composition (Table 1). According to Basso et al. (2012), pig slurry may have considerable amounts of heavy metals $(\mathrm{Cd}, \mathrm{Cr}$, and $\mathrm{Pb})$ due to the mineral supplement provided to the animals. Heavy metals are present as contaminants in the mineral supplements supplied with the feed. 
Table 4. Effect of nitrogen application rates on the micronutrient $(\mathrm{Cu}, \mathrm{Fe}, \mathrm{Mn}$, and $\mathrm{Zn})$ and toxic heavy metal $(\mathrm{Cd}, \mathrm{Cr}$, and $\mathrm{Pb}$ ) concentrations of the collard green (Brassica oleraceae var. acephala, cv. couve-manteiga) leaves.

\begin{tabular}{|c|c|c|c|c|c|c|c|}
\hline Nitrogen sources & $\mathrm{Cu}$ & $\mathrm{Fe}$ & $\mathrm{Mn}$ & $\mathrm{Zn}$ & $\mathrm{Cd}$ & $\mathrm{Cr}$ & $\mathrm{Pb}$ \\
\hline & \multicolumn{7}{|c|}{ 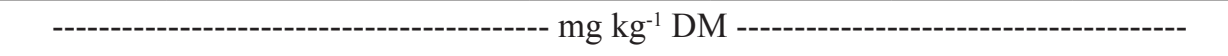 } \\
\hline Pig slurry & $9.4 \mathrm{a}$ & 239 a & $33.4 \mathrm{a}$ & $17.9 \mathrm{a}$ & $0.090 \mathrm{a}$ & $0.076 \mathrm{a}$ & $0.100 \mathrm{a}$ \\
\hline Poultry manure & $8.4 \mathrm{a}$ & $178 \mathrm{~b}$ & $20.8 \mathrm{~b}$ & $13.6 \mathrm{~b}$ & $0.040 \mathrm{ab}$ & $0.043 \mathrm{~b}$ & $0.044 \mathrm{ab}$ \\
\hline Urea & $7.2 \mathrm{a}$ & $154 \mathrm{~b}$ & $19.4 \mathrm{~b}$ & $13.6 \mathrm{~b}$ & $0.000 \mathrm{~b}$ & $0.021 \mathrm{~b}$ & $0.004 \mathrm{~b}$ \\
\hline F test & & & & F value & & & \\
\hline Source (S) & $2.10 \mathrm{~ns}$ & $4.97 *$ & $85.80^{* *}$ & $28.32^{* *}$ & $10.48 * *$ & $14.54 * *$ & $4.29 *$ \\
\hline \multicolumn{8}{|l|}{ Rate (R) } \\
\hline Linear regression & $37.55^{* *}$ & $15.05^{* *}$ & $111.89 * *$ & $63.94 * *$ & $13.51 * *$ & $29.18^{* *}$ & $2.52 \mathrm{~ns}$ \\
\hline Quadratic regression & $9.07^{* *}$ & $0.79 \mathrm{~ns}$ & $5.70^{*}$ & $2.16 \mathrm{~ns}$ & $0.10 \mathrm{~ns}$ & $0.08 \mathrm{~ns}$ & $0.00 \mathrm{~ns}$ \\
\hline Interaction $(\mathrm{S} \times \mathrm{R})$ & $0.30 \mathrm{~ns}$ & $0.66 \mathrm{~ns}$ & $10.23^{* *}$ & $4.69 * *$ & $2.59 *$ & $2.66^{*}$ & $0.62 \mathrm{~ns}$ \\
\hline CV $(\%)$ & 16.4 & 19.1 & 13.5 & 12.4 & 12.5 & 11.4 & 12.0 \\
\hline
\end{tabular}

Values represented by the different letters, for the nitrogen source show significant differences (Tukey test, $\mathrm{p}<0.05$ ). ns: not significant. $*$ and $* *$ : statistical significance at $5 \%$ and $1 \%$, respectively, by $\mathrm{F}$ test. $\mathrm{CV}$ : coefficient of variation.

Nitrogen application rates significantly linearly, respectively, in response to $\mathrm{N}$ rates (Figures influenced $(\mathrm{p}<0.05)$ the concentration of all $3 \mathrm{~A}$ and $3 \mathrm{~B})$. The maximum concentration of $\mathrm{Cu}$ micronutrients and heavy metals in the collard $\left(11.2 \mathrm{mg} \mathrm{kg}^{-1}\right)$ was obtained with the application leaves, except for $\mathrm{Pb}$ (Table 4 and Figure 3). For the $\quad$ of $270 \mathrm{mg} \mathrm{N} \mathrm{kg}^{-1}$ (Figure 3A). The $300 \mathrm{mg} \mathrm{N} \mathrm{kg}^{-1}$ $\mathrm{Cu}$ and $\mathrm{Fe}$ concentrations, there was no significant effect $(p>0.05)$ for the interaction between the $\mathrm{N}$ sources and rates factors (Table 4), and leaf $\mathrm{Cu}$ application increased the leaf $\mathrm{Fe}$ concentration in $84 \%$ (from 134.3 to $247.1 \mathrm{mg} \mathrm{kg}^{-1}$ ) compared to the unfertilized control with $\mathrm{N}$ (Figure 3B). and $\mathrm{Fe}$ concentrations increased quadratically and

Figure 3. Effect of nitrogen application rates on the concentration of copper (A), iron (B), manganese (C), zinc (D), cadmium (E) and chromium (F) in the collard green (Brassica oleraceae var. acephala, cv. couve-manteiga) leaves. Data refer to mean values $(\mathrm{n}=4) .{ }^{*}$ and $* *$ : statistical significance at $5 \%$ and $1 \%$, respectively, by $\mathrm{F}$ test. Vertical bars show the least significant difference (Tukey test, $\mathrm{p}=0.05$ ).
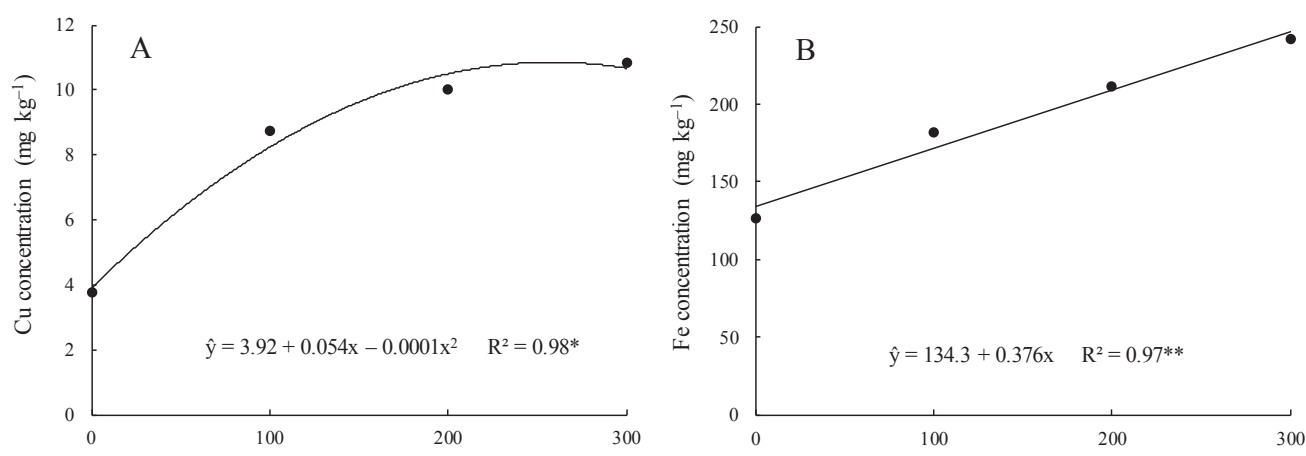

continue 
continuation
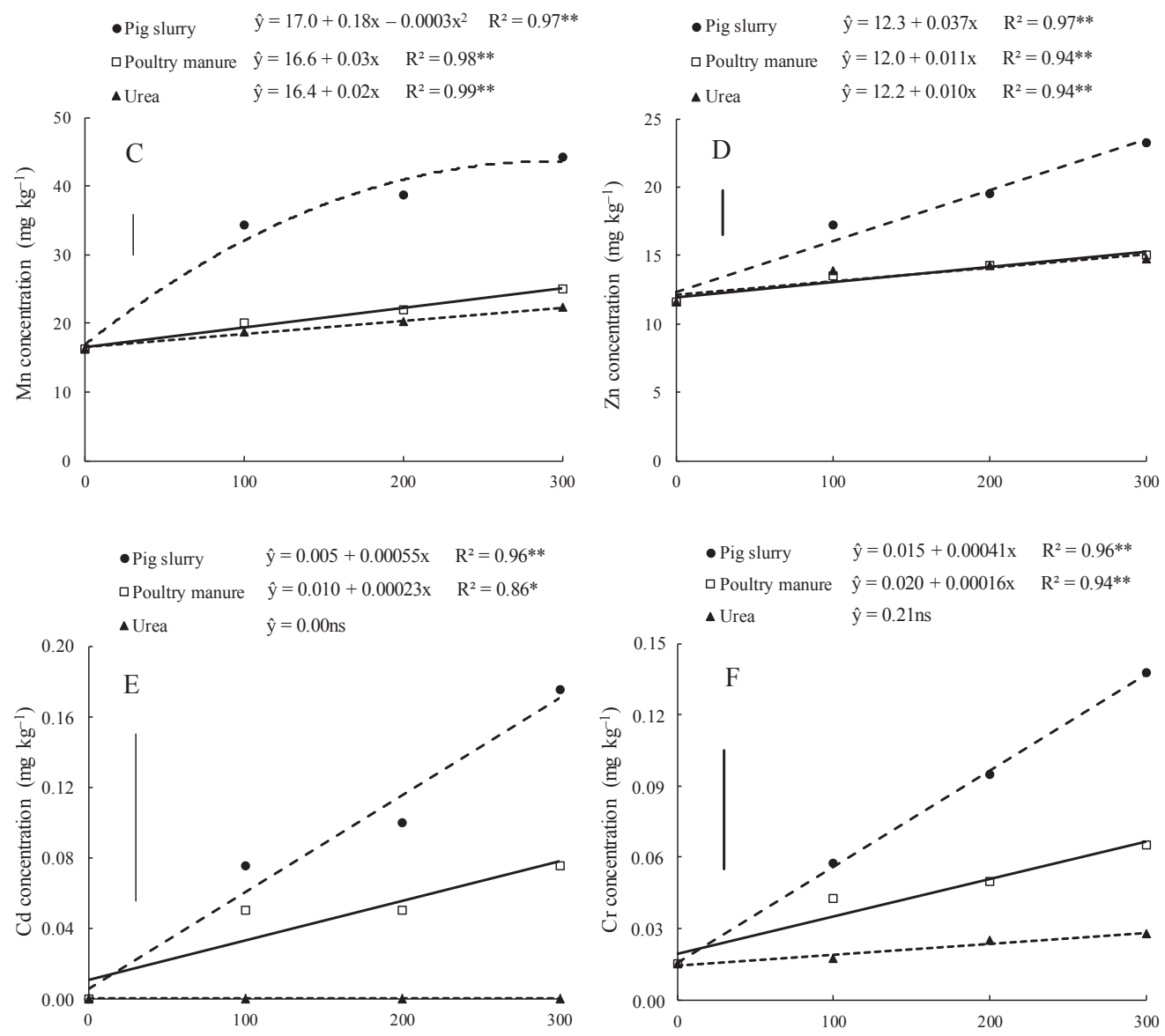

For the $\mathrm{Mn}, \mathrm{Zn}, \mathrm{Cd}$, and $\mathrm{Cr}$ concentrations a significant effect $(p<0.05)$ for the interaction between the $\mathrm{N}$ sources and rates was verified (Figure 3). Leaf Mn, $\mathrm{Zn}, \mathrm{Cd}$, and $\mathrm{Cr}$ concentrations increased progressively with increasing $\mathrm{N}$ fertilizer rates, and the highest values were obtained when the plants were fertilized with pig slurry (Figures 3). The $300 \mathrm{mg} \mathrm{N} \mathrm{kg}^{-1}$ application by the addition of urea, poultry manure, and pig slurry resulted in the increase of $37 \%, 54 \%$ and $159 \%$ in $\mathrm{Mn}$ concentration compared to the unfertilized treatment with N (Figure 3C). For the leaf $\mathrm{Zn}$ concentration, the increase was $24 \%, 27 \%$ and $90 \%$ for the addition of $300 \mathrm{mg} \mathrm{N} \mathrm{kg}^{-1}$ with urea, poultry manure, and pig slurry, respectively, in relation to the control without N (Figure 3D). These results are similar to those reported by Zanão Júnior et al. (2005), who also verified that the $\mathrm{N}$ rates applied in mock pak-

choi plants resulted in an increase in the leaf $\mathrm{Cu}, \mathrm{Mn}$ and $\mathrm{Zn}$ concentrations.

Leaf $\mathrm{Cu}$ and $\mathrm{Fe}$ concentrations in all treatments were within sufficiency range for collards (TRANI; RAIJ, 1997), i.e., $4-25 \mathrm{mg} \mathrm{kg}^{-1}$ for $\mathrm{Cu}$, and $60-300$ $\mathrm{mg} \mathrm{kg}{ }^{-1}$ for Fe. Except for the pig slurry application, the leaf $\mathrm{Mn}$ concentration was lower than 30 to $250 \mathrm{mg} \mathrm{kg}^{-1}$ (Figure 3C), the range considered appropriate for collards by Trani and Raij (1997). Leaf $\mathrm{Zn}$ concentration in all treatments was lower than the sufficiency range $\left(30-250 \mathrm{mg} \mathrm{kg}^{-1}\right)$ for collards (TRANI; RAIJ, 1997).

In the average of all treatments, the micronutrient uptake by the collard plants occurred in the following order: $\mathrm{Fe}>\mathrm{Mn}>\mathrm{Zn}>\mathrm{Cu}$ (Table 4 and Figure 3). These results confirm those reported by Zanão Júnior et al. (2005), who also verified that 
the accumulation of micronutrients in the mock pak-choi (Brassica chinensis L. var. parachinensis) leaves occurred in the following order: $\mathrm{Fe}>\mathrm{Mn}$ $>\mathrm{Zn}>\mathrm{B}>\mathrm{Cu}$. The results presented here show that cabbage can be an excellent source of minerals for human consumption, especially of $\mathrm{Fe}, \mathrm{Mn}, \mathrm{Zn}$ (Figure 3) and $\mathrm{Ca}$ (Figure 2).

The average concentrations of heavy metals in collard leaves varied with the $\mathrm{N}$ source applied (Table 4 and Figure 3). When the plants were fertilized with pig slurry, the accumulation of heavy metals in the leaves occurred in the following order: $\mathrm{Pb}>\mathrm{Cd}>\mathrm{Cr}$. With the application of poultry manure the accumulation of heavy metals was in the following order: $\mathrm{Pb}=\mathrm{Cr}>\mathrm{Cd}$. On the other hand, the application of mineral fertilizer resulted in the following order of accumulation of heavy metals in the leaves: $\mathrm{Cr}>\mathrm{Pb}>\mathrm{Cd}$. The $300 \mathrm{mg} \mathrm{N}$ $\mathrm{kg}^{-1}$ application by the addition of poultry manure and pig slurry resulted in the increase of 7.9 and 34.0 times the leaf $\mathrm{Cd}$ concentration compared to the urea application (Figure 3E). For the leaf $\mathrm{Cr}$ concentration, the increase was 3.4 and 9.2 times for the addition of $300 \mathrm{mg} \mathrm{N} \mathrm{kg}^{-1}$ with poultry manure and pig slurry, respectively, in comparison to urea application (Figure 3F). These results show that the order of accumulation of heavy metals in collard leaves depends on the source of nutrients applied, and the application of organic fertilizer results in greater accumulation of heavy metals. However, the heavy metal concentrations obtained in this study are well below the limits allowed by Brazilian legislation, as discussed below. Guerra et al. (2012) evaluating the quality of leafy vegetables consumed by the population of the São Paulo State also verified that the daily ingestion of heavy metals was below the oral dose of reference.

Considering that collard leaves had $14.89 \%$ (11.49 to $19.87 \%$ ) dry weight (Figure 1), the average concentrations (and range) of total $\mathrm{Cd}$, $\mathrm{Cr}$ and $\mathrm{Pb}$ in the leaf fresh mass were $0.008(0.00$ $0.042), 0.008$ (0.00-0.034) and 0.004 (0.00-0.030) $\mathrm{mg} \mathrm{kg}^{-1}$, respectively. Thus, the maximum values of
$0.042 \mathrm{mg} \mathrm{kg}^{-1} \mathrm{Cd}, 0.034 \mathrm{mg} \mathrm{kg}^{-1} \mathrm{Cr}$ and $0.030 \mathrm{mg}$ $\mathrm{kg}^{-1} \mathrm{~Pb}$ obtained in the fresh mass of collard leaves (i.e., edible portion of vegetable) are well below to the maximum daily ingestion limits of $0.07 \mathrm{mg}$ $\mathrm{Cd}, 105.0 \mathrm{mg} \mathrm{Cr}$ and $0.25 \mathrm{mg} \mathrm{Pb}$ established by the Brazilian legislation for an adult person of $70 \mathrm{~kg}$ of body weight. These threshold values are estimated from the oral reference dose $\left(\mathrm{R}_{\mathrm{f}} \mathrm{D}\right)$ for the maximum daily intake each heavy metal. The $\mathrm{R}_{\mathrm{f}} \mathrm{D}$ for $\mathrm{Cd}$ and Cr were set by the United States Environmental Protection Agency (US-EPA, 1998) at 0.001 and 1.5 $\mathrm{mg} \mathrm{kg}^{-1}$ of body weight per day, respectively, and the $\mathrm{R}_{\mathrm{f}} \mathrm{D}$ for $\mathrm{Pb}$ was set by the World Health Organization (WHO, 2004) at $0.0035 \mathrm{mg} \mathrm{kg}^{-1}$ of body weight per day. Therefore, to achieve the maximum acceptable daily intake indices of heavy metals an adult person of $70 \mathrm{~kg}$ could consume up to $1.67 \mathrm{~kg}$ of collards per day. These results indicate that the daily ingestion of heavy metals was below the oral dose of reference, therefore, consumption of collards from organic production systems with the application of animal manure can be considered safe and without risk to human health.

\section{Conclusions}

The manure application (pig slurry or poultry manure) resulted in collard green yield equivalent to the application of mineral fertilizer. However, the pig slurry application resulted in an increase of $\mathrm{Fe}$, $\mathrm{Mn}, \mathrm{Zn}, \mathrm{Cd}, \mathrm{Cr}$, and $\mathrm{Pb}$ concentrations in the leaves.

Nitrogen application rates up to $300 \mathrm{mg} \mathrm{N} \mathrm{kg}{ }^{-1}$ result in the higher yield and higher nutritional quality of collard green leaves.

The order of nutrient extraction by collard plants occurs in the following sequence: $\mathrm{N}=\mathrm{Ca}>\mathrm{K}>\mathrm{S}>\mathrm{P}>\mathrm{Mg}>\mathrm{Fe}>\mathrm{Mn}>\mathrm{Zn}>\mathrm{Cu}$, while for heavy metals the following general order follows: $\mathrm{Cr}=\mathrm{Cd}>\mathrm{Pb}$.

The application of high rates of manure, especially pig slurry, results in the increase of concentration of heavy metals $(\mathrm{Cd}, \mathrm{Cr}$, and $\mathrm{Pb})$ in collard leaves. 
However, the maximum concentrations of heavy metals well below than maximum daily intake limit established by the Brazilian legislation, indicating that the consumption of collards from organic production systems with the application of animal manure can be considered safe and without risk to human health.

\section{References}

ABREU, I. M. O.; JUNQUEIRA, A. M. R.; PEIXOTO, J. R.; OLIVEIRA, S. A. Qualidade microbiológica e produtividade de alface sob adubação química e orgânica. Ciência e Tecnologia de Alimentos, Campinas, v. 30, p. 108-118, 2010. Suplemento1. DOI: 10.1590/s010120612010000500018

AMBROSINI, V. G.; VOGES, J. G.; BENEVENUTO, R.; VILPERTE, V.; SILVEIRA, M. A.; BRUNETTO, G.; OGLIARI, J. B. Single-head broccoli response to nitrogen application. Cientifica, Jaboticabal, v. 43, n. 1, p. $84-92,2015$. DOI: $10.15361 / 1984-5529.2015 \mathrm{v} 43 \mathrm{n}$ $1 \mathrm{p} 84-92$

ARRUDA, C. A. O.; ALVES, M. V.; MAFRA, A. L.; CASSOL, P. C.; ALBUQUERQUE, J. A.; SANTOS, J. P. Aplicação de dejeto suíno e estrutura de um Latossolo Vermelho sob semeadura direta. Ciência e Agrotecnologia, Lavras, v. 34, n. 4, p. 804-809, 2010. DOI: 10.1590/s1413-70542010000400002

BASSO, C. J.; CERETTA, C. A.; MORAES FLORES, É. M.; GIROTTO, E. Teores totais de metais pesados no solo após aplicação de dejeto líquido de suínos. Ciência Rural, Santa Maria, v. 42, n. 4, p. 653-659, 2012. DOI: $10.1590 / \mathrm{s} 0103-84782012000400012$

CHARY, N. S.; KAMALA, C. T.; RAJ, D. S. S. Assessing risk of heavy metals from consuming food grown on sewage irrigated soils and food chain transfer. Ecotoxicology and Environmental Safety, Nova Iorque, v. 69 , n. 3, p. 513-524, 2008. DOI: 10.1016/j. ecoenv.2007.04.013

DARTORA, J.; GUIMARÃES, V. F.; ECHER, M. M.; PAULETTI, D. R.; MARINI, D. Análise de crescimento e produtividade do pak choi cultivado sob diferentes doses de nitrogênio. Revista Ceres, Viçosa, MG, v. 60 , n. 4, p. 498-504, 2013. DOI: 10.1590/s0034$737 \times 2013000400008$

DONAGEMA, G. K.; CAMPOS, D. V. B.; CALDERANO, S. B.; TEIXEIRA, W. G.; VIANA, J. H. M. Manual de métodos de análise de solo. 2. ed. Rio de Janeiro: EMBRAPA Solos, 2011. 230 p.
FILGUEIRA, F. A. R. Novo manual de olericultura: agrotecnologia moderna na produção e comercialização de hortaliças. 2. ed. Viçosa, MG: UFV, 2008. 421 p.

GONG, Y.; SOHN, H.; XUE, L.; FIRESTONE, G. L.; BJELDANES, L. F. 3,3'-Diindolylmethane is a novel mitochondrial $\left.\mathrm{H}^{+}\right)$-ATP synthase inhibitor that can induce $\mathrm{p} 21(\mathrm{Cip} 1 / \mathrm{Wafl})$ expression by induction of oxidative stress in human breast cancer cells. Cancer Research, Philadelphia, v. 66, n. 9, p. 4880-4887, 2006. DOI: 10.1158/0008-5472.can-05-4162

GUERRA, F.; TREVIZAM, A. R.; MURAOKA, T.; MARCANTE, N. C.; CANNIATTI-BRAZACA, S. G. Heavy metals in vegetables and potential risk for human health. Scientia Agricola, Piracicaba, v. 69, n. 1, p. 54-60, 2012. DOI: $10.1590 / \mathrm{s} 0103-90162012000100008$

KANO, C.; SALATA, A. C.; CARDOSO, A. I. I.; EVANGELISTA, R. M.; HIGUTI, A. R. O.; GODOY, A. R. Produção e qualidade de couve-flor cultivar Teresópolis Gigante em função de doses de nitrogênio. Horticultura Brasileira, Brasília, v. 28, n. 4, p. 453-457, 2010. DOI: $10.1590 / \mathrm{s} 0102-05362010000400013$

KONZEN, E. A.; ALVARENGA, R. C. Manejo $e$ utilização de dejetos animais: aspectos agronômicos e ambientais. Sete Lagoas: Ministério da Agricultura, Pecuária e Abastecimento, 2005. 16 p. (EMBRAPA Milho e Sorgo. Circular técnica, 63).

KOPSELL, D. A.; KOPSELL, D. E.; CURRANCELENTANO, J. Carotenoid pigments in kale are influenced by nitrogen concentration and form. Journal of the Science of Food and Agriculture, Easton, v. 87, n. 5, p. 900-907, 2007. DOI: 10.1002/jsfa. 2807

LIM, A. H.; VIMALA, P. Growth and yield responses of four leafy vegetables to organic fertilizer. Journal of Tropical Agriculture and Food Science, Kuala Lumpur, v. 40, n. 1, p. 1-11, 2012.

MIYAZAWA, M.; PAVAN, M. A.; MURAOKA, T.; CARMO, C. A. F. S.; MELO, W. J. Chemical analysis of plant tissues. In: SILVA, F. C. (Ed.). Manual of chemical analysis of soils, plants and fertilizers. Brasília: EMBRAPA Informação Tecnológica, 2009. p. 191-233.

SHINGO, G. Y.; VENTURA, M. U. Produção de couve Brassica oleracea L. var. acephala com adubação mineral e orgânica. Semina: Ciências Agrárias, Londrina, v. 30, n. 3, p. 589-594, 2009. DOI: 10.5433/1679-0359.2009v30n3p589

SILVA, T. O.; MENEZES, R. S. C.; TIESSEN, H.; SAMPAIO, E. V. S. B.; SALCEDO, I. H.; SILVEIRA, L. M. Adubação orgânica da batata com esterco e, ou, Crotalaria juncea. I - produtividade vegetal e estoque de nutrientes no solo em longo prazo. Revista Brasileira de 
Ciência do Solo, Viçosa, MG, v. 31, n. 1, p. 39-49, 2007. DOI: $10.1590 / \mathrm{s} 0100-06832007000100005$

SOUSA, D. M. G.; LOBATO, E. Cerrado: correção do solo e adubação. 2. ed. Planaltina: EMBRAPA Cerrados, 2004. $416 \mathrm{p}$.

TAIZ, L.; ZEIGER, E.; MØLLER, I. M.; MURPHY, A. Fisiologia e desenvolvimento vegetal. Porto Alegre: Artmed, 2017. $888 \mathrm{p}$.

TRANI, P. E.; RAIJ, B. Hortaliças. In: RAIJ, B.; CANTARELLA, H.; QUAGGIO, J. A.; FURLANI, A. M.

C. (Ed.). Recomendações de adubação e calagem para o estado de São Paulo. Campinas: Instituto Agronômico de Campinas, 1997. p. 155-185.

UNITED STATES ENVIRONMENTAL PROTECTION AGENCY - US-EPA. Toxicological review of cadmium and chromium. In: Chemical Assessment Summary of the Integrated Risk Information System (IRIS). Washington: USEPA, 1998.
WORLD HEALTH ORGANIZATION - WHO. Evaluation of certain food additives and Contaminants. In: Sixty-First Report of the Joint FAO/WHO Expert Committee on Food Additives. Geneva: WHO, 2004. (WHO Technical Series, 922)

XU, H. L.; WANG, R.; XU, R. Y.; MRIDHA, M. A. U.; GOYAL, S. Yield and quality of leafy vegetables grown with organic fertilizations. Acta Horticulturae, Bruxelas, v. 627 , n. 1, p. 25-33, 2003. DOI: $10.17660 /$ actahortic.2003.627.2

ZAGO, V. C. P.; EVANGELISTA, M. R.; ALMEIDA, D. L.; GUERRA, J. G. M.; NEVES, M. C. P.; RUMJANEK, N. G. Aplicação de esterco bovino e ureia na couve e seus reflexos nos teores de nitrato e na qualidade. Horticultura Brasileira, Brasília, v. 17, n. 3, p. 207-211, 1999. DOI: 10.1590/s0102-05361999000300006

ZANÃO JÚNIOR, L. A.; LANA, R. M. Q.; RANAL, M. A. Doses de nitrogênio na produção de couve-daMalásia. Horticultura Brasileira, Brasília, v. 23, n. 1, p. 76-80, 2005. DOI: 10.1590/s0102-05362005000100016 
